\title{
Target Keuangan, Kondisi Industri, Perubahan Auditor, dan Perubahan Direksi Terhadap Salah Saji Material pada Laporan Keuangan
}

\author{
Ari Purwanti * \\ Universitas Dian Nusantara \\ aripurwanti2501@gmail.com
}

*Corresponding Author

Diajukan $\quad: 8$ Februari 2022

Disetujui : 13 Februari 2022

Dipublikasi : 15 Februari 2022

\begin{abstract}
This study aims to investigate how financial targets, industry conditions, changes in auditors and changes in the Board of Directors can affect the occurrence of misstatements in financial statements. By using a research sample of 16 state-owned companies other than banks in 2015 to 2019, this study tested empirically using a multiple regression model. The partial test results prove that financial targets and changes in the auditor have a significant positive effect on material misstatements in the financial statements, but industry conditions have a significant negative effect on material misstatements in financial statements. Meanwhile, changes in directors have no significant effect on material misstatements in the financial statements. The $F$ test results give a significance value below $1 \%$ which means the research model is fit and the independent variables, namely financial targets, industry conditions, changes in auditors and changes in directors have a simultaneous effect on Material Misstatements in Financial Statements. The result of the coefficient of determination is 0.36 which means that the X1 variable (Financial Targets), X2 (Industrial Conditions), X3 (Auditor Changes) and X4 (Directorate Changes) variables together are able to provide an explanation of the Dependent variable, namely Misstatement The material is $36 \%$ while the remaining 64\% is explained by new variables that are not included in the model estimation. These results have implications for the practice of determining the materiality number against the background of the tendency of changes in the pattern of material misstatements in the financial statements under certain conditions.
\end{abstract}

Keywords: financial targets, nature of industry, changes in auditors, changes in directors of fraud in financial statements

\section{PENDAHULUAN}

Laporan keuangan yang diharapkan dapat memberikan informasi mengenai kondisi operasi perusahaan (Rahmayuni, 2018) dengan benar dan penyajiannya sesuai dengan standar yang berlaku umum, ternyata diperoleh bukti dari penelitian-penelitian sebelumnya dan kasus-kasus yang terungkap, terdapat potensi terjadinya salah saji. Pertimbangan auditor dalam menentukan salah saji dapat berupa salah saji karena kecurangan pelaporan keuangan dan salah saji karena penyalahgunaan aset (AICPA, 2002). Pada salah saji karena kecurangan memiliki motivasi yang sengaja direncanakan untuk memanipulasi, atau memalsukan, atau merubah pencatatan akuntansi dan dokumen pendukungnya, atau menyalahgunakan prinsip akuntansi/metode/pengungkapan. Sementara, salah saji yang terjadi karena adanya penyalahgunaan aset biasanya timbul karena penggelapan dan pencurian aset perusahaan.

Berdasarkan data dari The Association of Certified Fraud Examiners tahun 2019 (ACFE Indonesia, 2020), survei dengan responden pada badan usaha milik negara di Indonesia yang menduduki peringkat kedua dalam temuan kasus kecurangan yang terbesar, memperlihatkan salah saji akibat kecurangan pada laporan keuangan menduduki peringkat terbawah, yaitu tidak mencapai $7 \%$, diikuti dengan penyalahgunaan aset negara sekitar $29 \%$, dan terbanyak adalah korupsi lebih 
dari 64\%. Beberapa kasus yang terkuak sebelumnya, seperti kasus PT Garuda Indonesia, Tbk dan kasus-kasus di badan usaha milik negara lainnya (Ariyanto et al., 2021) yang ikut muncul ke permukaan pun seperti mendukung hasil survei tersebut (Yao et al., 2019).

Salah saji yang terjadi kemudian ditelusuri lebih dalam penyebab dan latar belakangnya (Dechow et al., 2011). Adanya tuntutan pencapaian target menjadi dugaan yang kuat mengapa banyak perusahaan melakukan tindakan salah saji yang material (Khadafi \& Terzaghi, 2019). Padahal, salah saji material ini dapat berdampak bagi pengguna laporan keuangan dalam pengambilan keputusan. Padahal, Statement of Auditing Standard No.99 sudah dengan sangat tegas menyatakan bahwa salah saji pada laporan keuangan akan menimbulkan masalah yang sangat signifikan. Oleh karena itu, penguatan kefektivitas auditor untuk dapat mendeteksi salah saji pada laporan keuangan yang diauditnya diperlukan untuk mengeliminasi terjadinya tindakan-tindakan penyimpangan tersebut (Genao, 2021). Meskipun, auditor tidak bertanggung jawab atas temuan kecurangan pada laporan keuangan.

Tindakan melakukan salah saji yang disengaja dapat terjadi karena stabilitas keuangan, tekanan dari pihak luar perusahaan, tekanan keuangan pribadi dan target keuangan yang ketat (Statement of Auditing Standard No. 99). Manajer perusahaan berusaha untuk dapat mencapai target keuangan yang telah ditetapkan karena kinerja mereka diukur dari hal tersebut. Target kerja yang dapat berupa pencapaian angka laba tertentu, memotivasi manajer untuk dapat menggunakan pilihan metode akuntansi yang tidak jarang menyimpang dari standar yang berlaku umum. Tidak jarang juga ditemukan sudah sesuai dengan standar akuntansi berlaku umum, namun besaran kesalahan penyajian ditemukan sangat material (Yao et al., 2019).

Di sisi lain, pertimbangan dari manajer sebagai pengambil keputusan atas operasi usaha diduga mendorong pola kebijakan keuangan yang relatif fleksibel dan subyektif dengan metodemetode yang mendukung pencapaian target keuangan (Nindito, 2018). Adanya kesempatan tersebut dimanfaatkan sebagai dasar alasan untuk mengejar target angka laba yang telah ditetapkan. Lemahnya pengawasan dan pengendalian internal serta struktur organisasi yang kurang stabil biasanya adalah kondisi dimana manajer memiliki kesempatan untuk secara subyektif mengambil keputusan yang berujung pada tindakan untuk menyajikan angka yang tidak seharusnya (Genao, 2021).

Terlebih lagi, apabila terdapat kondisi pergantian manajemen tingkat atas (Direksi). Fleksibilitas penetapan metode dan kebijakan dengan latar sifat industri yang akan diperbandingkan, merupakan tuntutan bagi manajemen (Direksi) baru untuk mencapainya. Penilaian keberhasilan manajemen tingkat atas (Direksi) yang baru dengan ukuran pembandingan hasil operasi dengan industri diduga dapat mendorong terjadinya salah saji pada laporan keuangan yang bersifat material. Keterbandingan dengan industri diduga dapat menurunkan tensi keinginan untuk melakukan salah saji material pada laporan keuangan.

Namun demikian, dalam usaha untuk menghilangkan jejak kegiatan pengambilan keputusan manajer dalam menyajikan angka laba yang tidak seharusnya, diantaranya adalah dengan mengganti auditor eksternal dalam proses pemeriksaan akhir periode pelaporan. Meskipun, penggantian auditor ini memang tidak menyalahi aturan yang berlaku, bahkan ada peraturan penggantian auditor eksternal setelah periode tertentu, namun motif penggantian auditor diduga dapat memuluskan penyajian angka dalam laporan keuangan yang tidak seharusnya. Manajer dapat melakukan manipulasi data bagi auditor pengganti karena dinilai auditor pengganti tidak memahami proses pencatatan pada periode sebelumnya dan pihak manajemen dapat menyatakan bahwa semua rekomendasi dari auditor sebelumnya telah dapat diselesaikan dengan baik.

Dengan latar belakang kondisi seperti yang terungkap, penelitian ini mencoba untuk menyelidiki bagaimana tuntutan target angka laba, fleksibilitas penetapan metode dan kebijakan akuntansi, dan pergantian manajemen tingkat atas (Direksi), sampai dengan upaya untuk mengganti auditor eksternal akan mempengaruhi terjadinya salah saji material pada pelaporan keuangan. Penelitian ini juga diharapkan dapat memberikan kontribusi pada pengetahuan bidang akuntansi, terutama bidang audit dalam hal penguatan pemahaman auditor dalam melakukan penetapan angka materialitas sehubungan dengan motif pola perilaku manajer pengambil keputusan akuntansi yang berubah sesuai dengan perubahan kondisi. 


\section{STUDI LITERATUR}

Kondisi penyajian yang salah secara material tidak lepas dari kemampuan dan kesempatan manajer melakukan tindakan-tindakan yang akan merugikan pengguna laporan keuangan. Adanya informasi yang asimetri mendorong timbulnya masalah keagenan antara manajemen dengan pemilik (Jensen \& Meckling, 1976). Pemilik yang menerima laporan keuangan yang dibuat oleh manajemen akan mengambil keputusan berdasarkan pada informasi keuangan yang tersaji. Padahal, laporan keuangan tersebut mengandung salah saji material.

Meskipun pada dasarnya manajer didelegasikan untuk mengelola dana yang diinvestasikan oleh pemilik dana, namun manajemen sebagai agen tidak jarang ditemukan lebih mengutamakan kepentingannya sendiri (oportunis) dibandingkan kepentingan pemilik (Scott, 2014). Perbedaan kepentingan yang timbul antara pemilik dan manajemen sebagai agen pemilik menimbulkan konflik yang mendorong manajer melakukan rasionalisasi untuk menyajikan angka akuntansi yang yang terlihat baik dan mencapai target.

Dorongan untuk melakukan penyajian yang tidak sesungguhnya dipicu adanya tuntutan pencapaian target keuangan yang harus dicapai manajemen dan biasanya ditetapkan dalam kontrak antara pemilik dengan manajemen. Motivasi ini juga dihadapi saat manajemen mengakomodasi peraturan yang mengikat dari pihak kreditur (Yesiariani \& Rahayu, 2017) dan pemangku kepentingan lain. Manajer dituntut untuk bekerja secara optimal dalam mencapai target perusahaan yang biasanya dinyatakan dalam tingkat pengembalian terhadap operasi aset usaha.

Terlebih pada saat persaingan pasar yang tinggi, diikuti dengan kemerosotan margin laba. Manajemen harus menghadapi tingginya kritik untuk perubahan dengan cepat, perubahan pada teknologi, produk yang tidak mengikuti trend, penilaian produk. Belum lagi adanya kemerosotan yang signifikan dari permintaan yang dapat meningkatnya kegagalan bisnis di beberapa industri atau keseluruhan dari ekonomi. Kerugian operasi yang mengakibatkan kebangkrutan, disita/ditutup, atau pengambilan alih perusahaan sering kali menjadi ancaman bagi perusahaan (Khadafi \& Terzaghi, 2019).

Arus kas yang minus berulang kali dari operasi dan tidak mampu untuk menghasikan arus kas dari operasi yang positif, tentunya menjadi trade-off apabila harus menyajikan angka laba yang positif dan bertumbuh. Ketat atau tingginya target pencapaian tingkat pengembalian atas kinerja aset menyebabkan manajer berupaya untuk menyajikan laporan keuangan dalam posisi yang sesuai dengan target tersebut. Karena bagi manajemen, pencapaian target adalah ukuran kinerja manajemen dan pencapaian target juga merupakan pengukuran batas bawah dari perolehan bonus.

Tekanan dari target keuangan ini diduga dapat meningkatkan kecenderungan manajemen untuk melakukan tindakan salah saji material pada laporan keuangan agar laporan keuangan tersaji sesuai dengan keinginan pemilik. Semakin tinggi tekanan target keuangan yang dihadapi manajemen, maka akan mendorong semakin tingginya keterjadian manajemen bertindak untuk melakukan salah saji material pada laporan keuangan. Oleh karena itu, penelitian ini mengembangkan hipotesis sebagai berikut.

Ha1: Tekanan target keuangan berpengaruh positif dan signifikan terhadap salah saji material pada laporan keuangan.

Lebih lanjut faktor lain yang juga diduga dapat mempengaruhi salah saji material pada laporan keuangan adalah kondisi industri. Kondisi industri dapat memicu manajemen untuk dapat membuktikan bahwa perusahaan telah dikelola dengan baik dan dapat bersaing dalam industri sebagai bukti pertumbuhannya. Manajemen berupaya menyajikan angka pada laporan akuntansi yang memberikan rasio-rasio aktivitas yang dapat memiliki hasil yang optimal ketika dibandingkan dengan industri.

Acuan rasio aktivitas yang paling sering untuk dibandingkan adalah rasio piutang dan rasio persedian karena kedua rasio ini adalah rasio yang memperlihatkan bahwa perusahaan dapat menjalankan operasi dengan lancar dan optimal. Ketika rasio aktivitas industri menunjukkan suatu angka, maka manajemen menjadikan angka tersebut acuan pencapaian dan bahkan berusaha untuk melampuinya agar dinilai berhasil dalam pengelolaan perusahaan (Pamungkas \& Utomo, 2018); (Skousen et al., 2019); dan (Richardson et al., 2006). 
Melalui fleksibilitas penentuan metode dan kebijakan akuntansi yang dimiliki manajemen dalam melakukan pencatatan akuntansi, maka manajemen berupaya untuk menyajikan laporan keuangan yang dapat menghasilkan angka melampaui rasio aktivitas industri. Situasi ini dapat menjadi menyimpang saat manajemen berupaya untuk menyajikan laporan keuangan yang di dalamnya terkadung kesalahan yang material. Ditambah lagi, bila perusahaan tidak memiliki pengendalian internal yang memadai. Hal ini dapat memberikan peluang kepada manajemen (Khadafi \& Terzaghi, 2019) untuk memberikan penilaian yang subyektif dalam menentukan dasar perhitungan rasio aktivitas, seperti pada kebijakan estimasi piutang yang tak tertagih dan susutnya persediaan (Nugraheni \& Triatmoko, 2017). Estimasi saldo piutang ditentukan secara subjektif dan manajemen dapat menggunakan akun tersebut untuk memanipulasi laporan keuangan dengan mengecilkan saldo penyisihan piutang tak tertagih, meskipun memiliki jumlah piutang kemungkinan besar memungkinkan sulit atau tidak dapat tertagih.

Dengan demikian, penelitian ini menduga semakin tinggi tuntutan kondisi industri dapat mendorong manajemen untuk menyajikan laporan keuangan yang mengandung salah saji material. Ha2: Kondisi industri berpengaruh positif signifikan terhadap salah saji material pada laporan keuangan.

Informasi kecurangan dengan menyajikan laporan keuangan yang mengandung salah saji material yang dilakukan oleh manajemen perusahaan dapat diketahui melalui temuan-temuan auditor (Saleh et al., 2021). Oleh karena itu, manajemen berupaya untuk menghilangkan jejak salah saji material yang ditemukan oleh auditor sebelumnya dengan menyampaikan bahwa semua rekomendasi atas temuan auditor sebelumnya telah diselesaikan. Pergantian auditor memungkinkan adanya suatu tindakan untuk menghilangkan jejak yang telah teridentifikasi oleh auditor sebelumnya guna menutupi kecurangan yang terjadi dalam perusahaan. Kecurangan juga dapat terjadi karena adanya sikap rasionalisasi oleh manajemen dan sikap tolerir yang diberikan oleh auditor melalui opini wajar tanpa pengecualian dengan kalimat penjelas. Berdasarkan justifikasi ini, penelitian ini menduga dalam hipotesis berikut.

Ha3: Pergantian Auditor berpengaruh positif signifikan terhadap salah saji material pada laporan keuangan.

Apabila kondisi perusahaan pada periode yang lalu tidak dalam posisi dapat mencapai target yang ditetapkan, tentunya memberikan implikasi pada penggantian manajemen tingkat atas (Direksi). Namun, apakah dengan penggantian Direksi dapat memastikan bahwa target perusahaan akan tercapai juga masih menjadi pertanyaan. Direksi baru boleh jadi dapat memperbaiki pencapaian target perusahaan.

Direksi baru memiliki motivasi untuk dapat memperlihat kinerja yang lebih baik dari Direksi sebelumnya. Dengan peluang berada pada posisi yang tinggi dalam manajemen melalui otoritas yang luas serta kepiawaiannya untuk mengambil keuntungan dengan kelemahan pengendalian internal, serta kemampuan penguasaan atas proses penyusunan laporan keuangan yang sangat memadai (Simaremare et al., 2019) dan (Rizani \& Respati, 2018) justru membuat Direksi yang baru yang terkadang berujung pada tindakan untuk menyajikan laporan keuangan yang mengandung salah saji material. Oleh karena itu, penelitan ini menduga seperti dalam hipotesis berikut.

Ha4: Pergantian Direksi berpengaruh positif signifikan terhadap salah saji material pada laporan keuangan.

\section{METODE}

Untuk menguji hipotesis yang dibangun dengan latar belakang permasalahan pada perusahaan badan usaha milik negara seperti yang diungkap sebelumnya, maka penelitian ini menggunakan sampel penelitian 16 perusahaan yang termasuk badan usaha milik negara selain industri keuangan. Alasan industri keuangan tidak dimasukkan dalam sampel karena indutri keuangan memiliki kondisi industri tanpa persediaan dan sangat diatur ketat pelaporannya oleh beberapa regulator.

Pengujian hipotesis pada penelitian ini dilakukan dengan model regresi berganda atas data- 
data keuangan yang dikumpulkan dari tahun 2015 sampai dengan 2019. Meskipun penelitian ini dilakukan pada tahun 2021, yang seharusnya memasukan data tahun 2020, namun peneliti berasumsi bahwa tahun 2020 adalah tahun awal terjadinya pandemi yang dapat menyebabkan bias pada data keuangannya bila digunakan dalam pengujian hipotesis pada penelitian ini.

Model regresi berganda yang digunakan untuk menguji hipotesis yang telah dibangun adalah sebagai berikut:

$$
\mathrm{SSM}=\mathrm{a}+\mathrm{b} 1 \mathrm{TK}+\mathrm{b} 2 \mathrm{KI}+\mathrm{b} 3 \mathrm{PA}+\mathrm{b} 4 \mathrm{PD}+\mathrm{e}
$$

Keterangan: SSM adalah salah saji material; TK adalah target keuangan; KI adalah kondisi industri; PA adalah pergantian auditor; dan PD adalah pergantian direksi; dengan a sebagai konstanta.

Pengukuran variabel dependen SSM, salah saji material menggunakan F-Score (Dechow et al., 2011) yang merupakan total penjumlahan perhitungan akrual (Richardson et al., 2006) dan kinerja keuangan diukur berdasarkan pengukuran (Skousen et al., 2019) melalui perubahan piutang, perubahan persediaan, perubahan penjualan tunai, dan perubahan pendapatan. Perhitungan akrual (Richardson et al., 2006), mendefinisikan semua perubahan non-tunai dan non-ekuitas dalam neraca perusahaan sebagai akrual dan membedakan karakteristik keandalan akrual modal kerja, akrual operasi tidak lancar, dan akrual pembiayaan dan komponen aset dan kewajiban pada jenis akrual. Klasifikasi ini dianggap baik untuk menjelaskan efek jangka pendek (di tahun mendatang) dan jangka panjang akrual laba masa depan, mengingat terdapat berbagai dampak jangka panjang mulai dari operasi perusahaan, investasi dan pendanaan untuk kinerja masa depan.

Sedangkan dalam mengukur kinerja keuangan, (Dechow et al., 2011) menyarankan bahwa manipulasi yang dilakukan dengan perubahan piutang dapat berdampak pada peningkatan pertumbuhan penjualan. Manipulasi dilakukan dengan perubahan akun persediaan dapat berdampak pada peningkatan margin kotor. Pengukuran perubahan penjualan tunai digunakan untuk mengevaluasi apakah penjualan yang tidak tunduk pada manajemen akrual menurun. Perubahan dalam pendapatan juga dianalisis karena manajer tampaknya lebih memilih untuk menunjukkan pertumbuhan pendapatan yang positif. Selama periode manipulasi, manajer cenderung menggunakan akrual untuk menunjukkan peningkatan laba yang positif (Pamungkas \& Utomo, 2018) (Pamungkas et al., 2018).

Pengukuran variabel TK menggunakan rasio profitabilitas sebagai hasil kinerja perusahaan. pengukuran variabel KI diproksi dengan rasio piutang. Pengukuran variabel PA dan PD adalah dengan menggunakan dummy dengan nilai 1 , bila terjadi penggantian dan 0 , bila lainnya.

\section{HASIL}

Sebelum melakukan pengujian hipotesis, penelitian ini melakukan pamaparan hasil statistik deskriptif dari data yang telah dikumpulkan dengan tujuan untuk melihat karakter data yang akan digunakan dalam pengujian. Dari data yang digunakan pada penelitian ini, nilai F-Score sebagai proksi dari salah saji material memiliki rata-rata sebesar 0,15 dengan range sepanjang - 0,55 sampai dengan 0,93 dan standar deviasi sebesar 0,37. Sebaran ini memperlihatkan perusahaan sampel yang memiliki kualitas akrual dan kinerja keuangan yang positif lebih banyak dari pada perusahaan yang memiliki kualitas akrual dan kinerjan keuangan yang negatif.

\section{Tabel 1}

Uji Statistik Deskriptif Descriptive Statistics

\begin{tabular}{rr|r|r|r|r} 
& $\mathrm{N}$ & Minimum & Maximum & Mean & Std. Deviation \\
\hline TK & 70 &,- 15377 &, 57531 &, 0450281 &, 08824712 \\
\hline KI & 70 &,- 19642 &, 47331 &, 0374806 &, 10124542 \\
\hline
\end{tabular}


Owner: Riset \& Jurnal Akuntansi

e-ISSN : 2548-9224 |p-ISSN : 2548-7507

Volume 6 Nomor 1, Januari 2022

DOI : https://doi.org/10.33395/owner.v6i1.739

\begin{tabular}{|c|r|r|r|r|r|r|}
\hline PA & 70 & 0 & 1 &, 30 &, 462 \\
\hline PD & 70 & 0 & 1 &, 70 &, 462 \\
\hline SSM & 70 &,- 54925 &, 92781 &, 1499187 &, 37285002 \\
\hline Valid N (listwise) & 70 & & & & \\
\hline
\end{tabular}

Untuk data TK yang diukur dengan ROA menunjukan rata-rata sebesar 0,045 dengan nilai terendah sebesar -0,15 dan nilai tertinggi sebesar 0,58 dan standar deviasi sebesar 0,09. Sebaran ini memperlihatkan hampir semua tahun-perusahaan sample pada tingkat profitabilitas positif, kecuali 2 data pada tahun tertentu yang bernilai negatif. Selanjutnya untuk data KI menunjukan rata-rata rasio piutang sebesar 0,037 dengan nilai terendah sebesar $-0,196$ dan nilai tertinggi sebesar 0,473 serta standar deviasi sebesar 0,101 . Sebaran ini memperlihatkan variasi perusahaan yang memiliki rasio piutang yang bernilai negatif dan positif. Sementara untuk data PA memperlihatkan yang mengganti auditor dari tahun-perusahaan sampel sebanyak 30\% dan melakukan penggantian Direksi sebesar $70 \%$.

Setelah diketahui sebaran dari data yang akan digunakan dalam pengujian hipotesis penelitian ini, dilakukan uji asumsi klasik yang memastikan bahwa data yang digunakan dalam pengujian tidak mengandung masalah normalitas, heteroskedastisitas, autokorelasi, dan mulikolineritas.

Tabel 2

Uji Normalitas

One-Sample Kolmogorov-Smirnov Test

\begin{tabular}{llr}
\hline $\mathrm{N}$ & & Unstandardized Residual \\
\hline Normal Parameters & & 70 \\
& Mean &, 0000000 \\
\cline { 2 - 3 } & Std. Deviation &, 29822117 \\
\hline Most Extreme Differences & Absolute &, 088 \\
\cline { 2 - 3 } & Positive &, 088 \\
\cline { 2 - 3 } & Negative &,- 051 \\
\hline Test Statistic & &, 088 \\
\hline Asymp. Sig. (2-tailed) & &, $200^{\mathrm{c}, \mathrm{d}}$ \\
\hline
\end{tabular}

a. Test distribution is Normal.

b. Calculated from data.

c. Lilliefors Significance Correction.

$\mathrm{d}$. This is a lower bound of the true significance.

Tabel 3

Uji Multikolinearitas

Coefficients $^{\mathrm{a}}$

\begin{tabular}{|c|c|c|c|c|c|c|c|}
\hline \multirow[b]{2}{*}{ Model } & \multicolumn{2}{|c|}{$\begin{array}{l}\text { Unstandardized } \\
\text { Coefficients }\end{array}$} & \multirow{2}{*}{$\begin{array}{c}\text { Standardized } \\
\text { Coefficients } \\
\text { Beta }\end{array}$} & \multirow[b]{2}{*}{$\mathrm{T}$} & \multirow[b]{2}{*}{ Sig. } & \multicolumn{2}{|c|}{$\begin{array}{c}\text { Collinearity } \\
\text { Statistics }\end{array}$} \\
\hline & $\mathrm{B}$ & Std. Error & & & & Tolerance & VIF \\
\hline 1 (Constant) & ,096 &, 074 & & 1,295 & 200 & & \\
\hline TK & ,779 & ,422 & , 184 & 1,843 & ,070 & ,984 & 1,016 \\
\hline
\end{tabular}


Owner: Riset \& Jurnal Akuntansi

e-ISSN : 2548-9224 | p-ISSN : 2548-7507

Volume 6 Nomor 1, Januari 2022

DOI : https://doi.org/10.33395/owner.v6i1.739

\begin{tabular}{l|r|r|r|r|r|r|r|r}
\hline KI & $-1,527$ &, 371 &,- 415 & - &, 000 &, 968 & 1,033 \\
& & & & 4,111 & & & \\
\hline PA &, 271 &, 082 &, 335 & 3,302 &, 002 &, 956 & 1,047 \\
\hline PD &,- 007 &, 082 &,- 009 &,- 089 &, 929 &, 947 & 1,056 \\
\hline
\end{tabular}

a. Dependent Variable: SSM

Tabel 4

Uji Heteroskedastisitas - Uji Glejser

Coefficients $^{\mathrm{a}}$

\begin{tabular}{|c|c|c|c|c|c|c|}
\hline \multirow{2}{*}{\multicolumn{2}{|c|}{ Model }} & \multicolumn{2}{|c|}{$\begin{array}{l}\text { Unstandardized } \\
\text { Coefficients }\end{array}$} & \multirow{2}{*}{$\begin{array}{l}\text { Standardized } \\
\text { Coefficients } \\
\text { Beta }\end{array}$} & \multirow[b]{2}{*}{$\mathrm{t}$} & \multirow[b]{2}{*}{ Sig. } \\
\hline & & B & Std. Error & & & \\
\hline \multirow[t]{5}{*}{1} & (Constant) & ,249 &, 046 & & 5,416 &, 000 \\
\hline & TK &,- 202 & ,262 &,- 094 &,- 769 & ,444 \\
\hline & $\mathrm{KI}$ &, 325 & ,231 &, 174 & 1,410 & , 163 \\
\hline & PA &, 011 &, 051 &, 026 &, 212 & ,833 \\
\hline & PD &,- 039 & 051 &,- 094 &,- 755 & ,453 \\
\hline
\end{tabular}

a. Dependent Variable: ABRESID

Hasilnya membuktikan berdasarkan hasil uji statistik Kolmogorov-Smirnov Test bahwa data residual dalam model regresi sudah terdistribusi dengan normal karena nilai signifikansi alpha sebesar 0,200 lebih besar dari 0,05. Kemudian hasil nilai VIF semua variabel pengujian bernilai di bawah angka 10, yang berarti data yang digunakan terbebas dari masalah multikolinearitas, tidak ada korelasi antara variabel independennya. Demikian halnya dengan hasil uji glejser, yang membuktikan semua nilai $t$ di atas 0,05 , yang berarti bahwa semua data variabel yang digunakan dalam pengujian terbebas dari masalah heteroskedastisitas. Kemudian yang terakhir adalah pengujian autokorelasi, hasil uji Durbin-Watson membuktikan bahwa nilai Durbin-Watson sebesar 2,025, nilai dL sebesar 1,4637, nilai dU sebesar 1,7683, nilai 4-dL sebesar 2,5363, dan nilai 4-dU 2,2317. Maka dapat disimpulkan bahwa model regresi terbebas dari gejala autokorelasi, karena nilai Durbin-Watson berada diantara dU - dL, dan 4-dU - 4-dL.

Setelah dipastikan data sudah BLUE (best linear unbiased estimated), maka pengujian model penelitian dengan menggunakan regresi berganda dilakukan dan hasilnya disajikan pada tabel 1 berikut.

\begin{tabular}{|c|c|c|c|c|c|c|}
\hline \multirow[b]{3}{*}{ Mode } & \multicolumn{6}{|c|}{$\begin{array}{l}\text { Tabel } 5 \\
\text { Hasil Regresi } \\
\text { Coefficients }^{\mathrm{a}}\end{array}$} \\
\hline & & \multicolumn{2}{|c|}{ Unstandardized Coefficients } & \multirow{2}{*}{$\begin{array}{l}\text { Standardized } \\
\text { Coefficients } \\
\text { Beta }\end{array}$} & \multirow[b]{2}{*}{$\mathrm{T}$} & \multirow[b]{2}{*}{ Sig. } \\
\hline & & $\mathrm{B}$ & Std. Error & & & \\
\hline \multirow[t]{5}{*}{1} & (Constant) & ,096 & ,074 & & 1,295 & 200 \\
\hline & TK & ,779 &, 422 & ,184 & 1,843 &, 070 \\
\hline & KI & $-1,527$ & ,371 &,- 415 & $-4,111$ & ,000 \\
\hline & PA & ,271 & ,082 & ,335 & 3,302 & ,002 \\
\hline & PD &,- 007 & 082 &,- 009 &,- 089 & ,929 \\
\hline
\end{tabular}

a. Dependent Variable: SSM 
Berdasarkan hasil uji-t pada Tabel 1 membuktikan hipotesis 1, 2, dan 3 terbukti signifikan, dan hanya hipotesis 4 yang tidak terbukti signifikan.

\begin{tabular}{|c|c|c|c|c|c|}
\hline \multirow[b]{2}{*}{ Model } & \multicolumn{3}{|c|}{$\begin{array}{c}\text { Tabel 6 } \\
\text { Uji Anova } \\
\text { ANOVA }^{\mathrm{a}}\end{array}$} & \multirow[b]{2}{*}{$\mathrm{F}$} & \multirow[b]{2}{*}{ Sig. } \\
\hline & Sum of Squares & df & Mean Square & & \\
\hline 1 Regression & 3,456 & 4 &, 864 & 9,151 &, $000^{\mathrm{b}}$ \\
\hline Residual & 6,137 & 65 & ,094 & & \\
\hline Total & 9,592 & 69 & & & \\
\hline
\end{tabular}

Berdasarkan hasil output SPSS 26 untuk menguji model penelitian, secara empiris uji-F memberikan nilai signifikasi di bawah $1 \%$ yang berarti bahwa model penelitian telah fit dan semua variabel yang digunakan dapat digunakan sebagai model pengujian hipotesis.

Tabel 7

Koefisien Determinasi

Model Summary ${ }^{\mathrm{b}}$

\begin{tabular}{lr|r|r|r} 
Model & R & R Square & Adjusted R Square & Std. Error of the Estimate \\
\hline 1 &, $600^{\mathrm{a}}$ &, 360 &, 321 &, 30726022 \\
\hline
\end{tabular}

a. Predictors: (Constant), TK, KI, PA, PD

b. Dependent Variable: SSM

Hasil Uji Koefisien Determinasi (R-square) membuktikan secara empiris target keuangan, kondisi industri, penggantian auditor dan penggantian direksi dapat menjelaskan besarnya salah saji material pada laporan keuangan sebesar 36\%, sementara 64\% sisanya dijelaskan oleh faktor lain yang tidak dimasukkan dalam pengujian ini.

\section{PEMBAHASAN}

Hipotesis 1 yang menduga bahwa tekanan target keuangan berpengaruh positif dan signifikan terhadap salah saji material pada laporan keuangan, berdasarkan hasil pengujiannya terbukti signifikan pada level alpha $10 \%(0,070<0,1)$. Konsisten dengan penelitian sebelumnya bahwa semakin tinggi tekanan target keuangan yang dihadapi manajemen, maka akan mendorong semakin tingginya keterjadian manajemen bertindak untuk melakukan salah saji material pada laporan keuangan (Pamungkas et al., 2018).

Perusahaan dengan kepemilikan negara biasanya telah ditetapkan hasil kinerja yang ketat, karena perusahaan sebagai lembaga negara berfungsi untuk dapat meningkatkan kersejahteraan masyarakat secara umum (Yao et al., 2019). Keberhasilan manajemen untuk dapat mengelola aset negara dengan efisien dan terukur pada perolehan laba yang tersaji pada laporan keuangan. Untuk mencapai angka laba yang telah ditargetkan, manajemen melakukan kebijakan-kebijakan akrual dalam transaksi operasional. Melalui kebijakan akrual modal kerja, akrual operasi yang berdurasi jangka panjang, dan akrual pembiayaan menjadi penting untuk dilakukan justifikasi dalam menjelaskan efek akrual laba (Dechow et al., 2011). Kebutuhan akan proyeksi kondisi keuangan masa depan juga menjadi hal yang harus dimasukkan saat pertimbangan besaran angka yang akan disajikan pada laporan keuangan (Pamungkas et al., 2018).

Perubahan-perubahan pencatatan piutang, persediaan, dan pendapatan yang bersifat nontunai dan non-ekuitas dalam laporan posisi keuangan dilakukan penyesuaian yang dianggap dapat memberikan dampak saat ini dan masa depan dari sisi operasi, investasi dan pembiayaan. Ketat atau tingginya target pencapaian tingkat pengembalian atas kinerja aset menyebabkan dengan serangkaian proses penyesuaian mendorong manajer berupaya untuk menyajikan laporan keuangan dalam posisi yang sesuai dengan target yang telah ditetapkan. 
Di sisi lain, pencapaian target ini juga berdampak bagi perolehan insentif bagi manajamen apabila dapat melampauinya (Saleh et al., 2021). Tekanan dari target keuangan dan motivasi untuk mencapai target keuangan ini diduga dapat meningkatkan kecenderungan manajemen untuk melakukan tindakan salah saji material pada laporan keuangan agar laporan keuangan tersaji sesuai dengan keinginan pemilik (Skousen et al., 2019).

Pencapaian target keuangan ini tentunya juga sangat bergantung pada kondisi industri usaha. Pada kondisi industri yang tinggi, memicu perusahaan untuk dapat melampaui standar industri. Pada kondisi perusahaan dengan kepemilikan negara, bahkan telah diatur secara ketat melalui pengukuran beberapa rasio aktivitas untuk melihat efektifitas manajemen dalam pengelolaan aset negara (Genao, 2021). Memastikan bahwa terjadi perputaran yang optimal atas pengoperasian aset lancar menjadi acuan bahwa perusahaan dapat bertumbuh agar semakin banyak manfaat untuk kesejahteraan masyarakat secara umum. Optimalisasi penggunaan aset dalam ukuran rasio piutang dan rasio persediaan sebagai rasio aktivitas menjadi ukuran bagi perusahaan untuk bisa memperlihatkan roda operasi usaha melaju dengan optimal.

Untuk itu, dalam menjelaskan hasil pengujian pada hipothesis 2, yang mana dalam pembangunan hipotesis 2 menyatakan bahwa kondisi industri berpengaruh positif signifikan terhadap salah saji material pada laporan keuangan. Namun, dalam penelitian ini justru memberikan bukti yang berlawanan arahnya, berpengaruh negatif signifikan. Hasil pengujian membuktikan bahwa semakin tinggi rasio perputaran piutang justru mendorong manajemen untuk mengurangi salah saji secara material pada laporan keuangannya.

Penjelasan atas hasil yang berlawanan arah dari hipotesisnya ini, memperlihatkan bahwa tindakan manajemen untuk menyajikan kesalahan yang material pada laporan keuangan dapat direduksi dengan perputaran piutang yang tinggi (Pamungkas et al., 2018). Apabila perusahaan memiliki perputaran piutang yang tinggi, maka hasil ini akan mengoreksi kualitas akrual dan kinerja keuangan. Perputaran piutang yang tinggi, artinya perusahaan dapat mengolah aset perusahan dengan sangat efisien, tidak ada aset yang terlalu lama penguasaannya pada pihak pelanggan. Boleh jadi karena kondisi industri perusahaan dengan kepemilikan negara memiliki ketentuan dan persyaratan yang ketat untuk transaksi kepada pihak ketiga. Sehingga, tidak memerlukan durasi pelunasan yang lama dari para pelanggan. Dengan demikian, tingginya perputaran piutang justru malah dapat memperkecil salah saji material pada laporan keuangan.

Selanjutnya, hasil pengujian untuk hipotesis 3 yang menyatakan bahwa pergantian Auditor berpengaruh positif signifikan terhadap salah saji material pada laporan keuangan, berdasarkan hasil pengujian pada Tabel 1 hipotesis 3 terbukti. Konsisten dengan penelitian sebelumnya, adanya indikasi bahwa penggantian auditor dilakukan dalam upaya untuk menutupi jejak kecurangan masa lalu yang menyebabkan salah saji material, maka manajemen merasa perlu untuk konsisten melakukan penyajian laporan keuangan yang mengandung salah saji material. Boleh jadi, manajemen enggan untuk mengubah kebijakan yang telah berlaku sebalumnya, sehingga salah saji material yang pada periode sebelumnya terjadi, maka di periode berikutnya pun akan terbawa.

Dibandingkan dengan menggunakan auditor yang sama pada periode yang lalu dengan konseksuensi akan menyelesaian semua rekomendasi dari auditor eksternal akibat temuan salah saji, mendorong manajemen untuk memilih alternatif yang sedikit usaha namun memberikan manfaat yang besar tanpa mengubah kebijakan yang telah berlaku.

Namun, tidak demikian dengan penggantian Direksi. Hasil pengujian model penelitian membuktikan bahwa hipotesis 4 tidak terbukti. Penggantian Direksi berpengaruh positif, namun tidak signifikan terhadap besarnya salah saji material pada laporan keuangan. Hasil ini memberikan implikasi bahwa rasionalisasi dan kapabilitas Direksi untuk dapat mempengaruhi proses penyusunan laporan keuangan tidak terbukti signifikan dapat mempengaruhi penyajian laporan keuangan yang salah saji. Intensi dan insentif yang diperoleh dari penggantian Direksi bukan sebagai penentu terjadinya atau besarnya salah saji material pada laporan keuangan.

\section{KESIMPULAN}

Berdasarkan hasil penelitian mengenai pengaruh Target Keuangan, Kondisi Industri, Perubahan Auditor dan Perubahan Direksi terhadap Salah Saji Material Pada Laporan Keuangan, maka dapat diambil kesimpulan sebagai berikut : Hasilnya secara empiris membuktikan bahwa 
tekanan target keuangan dan penggantian auditor berpengaruh positif signifikan terhadap besarnya salah saji material pada laporan keuangan namun kondisi industri terbukti dapat memberikan pengaruh negatif signifikan pada besarnya salah saji material pada laporan keuangan sedangkan penggantian Direksi terbukti berpengaruh tidak signifikan dalam mempengaruhi besarnya salah saji material pada laporan keuangan. Hasil penelitian ini diharapkan dapat memberikan kontribusi bagi pengetahuan di bidang audit bahwa model-model deteksi kecurangan dengan melakukan penyajian laporan keuangan yang mengandung salah saji material harus disertai dengan indikator yang komprehensif atas lingkungan audit dan karakteristik industri yang akan diaudit, seperti yang juga diungkapkan oleh (Genao, 2021). Sementara itu, hasil penelitian ini dapat memberikan implikasi praktik audit untuk lebih melakukan penguatan dan kehati-hatian pada aspek-aspek penentuan materialitas yang berkaitan dengan hal-hal yang yang terdeteksi dapat memicu terjadainya penyajian angka akuntansi yang mengandung motif tindakan salah saji material.

\section{REFERENSI}

ACFE Indonesia. (2020). Survei Fraud Indonesia 2019. ACFE Indonesia, 72. https://doi.org/10.1017/CBO9781107415324.004

American Institute of Certified Public Accountants. (2002). AU Section 316 Consideration of Fraud in a Financial. October, 99, 113, 167-218.

Ariyanto, D., Jhuniantara, I. M. G., Ratnadi, N. M. D., \& Putri, I. G. A. M. A. D. (2021). Fraudulent Financial Statements in Pharmaceutical Companies: Fraud Pentagon Theory Perspective. Journal of Legal, Ethical and Regulatory Issues, 24(6).

Dechow, P. M., GE, W., Larson, C. R., \& SLoan, R. G. (2011). Predicting Material Accounting Misstatements. Contemporary Accounting Research, 28(1), 17-82.

Genao, D. R. (2021). Identification of Fraudulent Financial Statements: The Detection of Deception and Collusion in Earnings Calls. Northcentral University School of Business.

Jensen, M. C., \& Meckling, W. H. (1976). Theory of the firm : Managerial behavior, agency costs and ownership structure. Journal of Financial Economics, 3(4), 305-360. https://doi.org/10.1016/0304-405X(76)90026-X

Khadafi, M., \& Terzaghi, M. T. (2019). Pengaruh FRAUD Pentagon Dalam Mendeteksi Kecurangan Laporan Keuangan. https://doi.org/10.31955/mea.vol3.iss1.pp44-62

Nindito, M. (2018). Financial Statement FRAUD : Perspective Of The Pentagon FRAUD Model In Indonesia. Academy of Accounting and Financial Studies Journal, 22(2), 1-9.

Nugraheni, N. K., \& Triatmoko, H. (2017). Analisis Faktor-Faktor Yang Mempengaruhi Terjadinya Financial Statement Fraud: Perspektif Diamond Fraud Theory (Studi Pada Perusahaan Perbankan Yang Terdaftar Di Bursa Efek Indonesia Periode 2014-2016). Jurnal AKuntansi Dan Auditing, 14(2), 118-143. https://doi.org/10.14710/jaa.v14i2.19774

Pamungkas, Dapit, I., \& Utomo, S. D. (2018). Fraudulent Financial Reporting: An Application of Fraud Pentagon Theory to Association of Southeast Asian Nations Corporate Governance Scorecard. Journal of Advanced Research in Law and Economics, 9(5 (35)), 1729-1737.

Pamungkas, I. D., \& Utomo, S. D. (2018). Fraudulent Financial Reporting : An Apllication of Fraud Pentagon Theory to Association of Southeast Asian Nations Corporate Governance Scorecard. Journal of Advanced Research in Law and Economics, 9(5).

Rahmayuni, S. (2018). Analisis Pengaruh Fraud Diamond Terhadap Kecurangan Laporan Keuangan (Studi Empiris Pada Perusahaan Manufaktur Yang Terdaftar Di BEI Tahun 20132016). Journal Akuntansi Universitas Negeri Padang, 6, 1-20.

Richardson, S. A., SLoan, R. G., \& Tuna, A. I. (2006). The Implications of Accounting Distortions and Growth for Accruals and Profitability. The Accounting Review, 81(3), 713-743.

Rizani, F., \& Respati, N. W. (2018). Factors Influencing The Presentation Of Fraudulent Financial Reporting in Indonesia. Journal of Advanced Research in Law and Economics, 9(1 (31)), 254-264.

Saleh, Abdullah, M. M., Aladwan, M., Alsinglawi, O., \& Saleh, H. M. I. (2021). Predicting Fraudulent Financial Statements Using FRAUD Detection Models. Academy of Strategic Management Journal, 20, 1-17.

Scott, W. R. (2014). Financial Accounting Theory, 7th Edition. Pearson Education. 
Owner: Riset \& Jurnal Akuntansi

e-ISSN : 2548-9224 |p-ISSN : 2548-7507

Volume 6 Nomor 1, Januari 2022

https://doi.org/0133499804

Simaremare, E., Handayani, C., Basri, H., Tambunan, A., \& Umar, H. (2019). Pengaruh Fraud Diamond Terhadap Pendeteksian Fraudulent Financial Statement Dengan Kebijakan Anti Fraud Sebagai Variabel Moderasi Pada Perusahaan Perbankan Yang Terdaftar Di Bursa Efek Indonesia Tahun 2016-2018. PROSIDING SEMINAR NASIONAL CENDEKIAWAN 2019 BUKU II. https://doi.org/10.25105/semnas.v0i0.5778

Skousen, C. J., R, K., \& Wright, C. J. (2019). Detecting And Predicting Financial Statement Fraud : The Effectiveness of the Fraud Triangle and SAS No.99. Corporate Governance and Firms Performance, 13, 23-81.

Yao, J., Pan, Y., Yang, S., Chen, Y., \& Li, Y. (2019). Detecting Fraudulent Financial Statements For The Sustainable Development Of The Socio-Economy In China: A Multi-Analytic Approach. Sustainability, 11(6), 1579.

Yesiariani, M., \& Rahayu, I. (2017). Deteksi Financial Statement Fraud : Pengujian Dengan Fraud Diamond. Jurnal Akuntansi Dan Auditing Indonesia, 21(1), 49-60. https://doi.org/10.20885/jaai.vol21.iss1.art5 